\title{
ANALISIS PROFIT ABILITAS LEMBAGA PERKREDITAN DESA BERDASARKAN CASH TURNOVER, CREDIT TURNOVER DAN RECEIVABLE TURNOVER
}

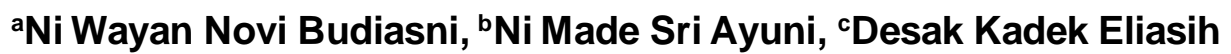

abc Sekolah Tinggi IImu Ekonomi Satya Dharma

n.budiasni@gmail.com

\begin{abstract}
ABSTRAK
Analisis Profitabilitas Lembaga Perkreditan Desa Berdasarkan Cash Turnover, Credit Turnover, dan Receivable Turnover. Penelitian ini bertujuan untuk mengetahui tingkat profitabilitas LPD Desa Adat Penarukan menggunakan rasio Cash Turnover, Credit Turnover, dan Receivable Turnover. Metode penelitian menggunakan metode kuantitatif deskriptif. Menggunakan data laporan keuangan LPD (data sekunder) tahun 2018-2020. Hasil penelitian ditemukan bahwa Net Profit Margin mencapai 26,8\% sudah sesuai standar industri. Namun Gross Profit Margin, ROA dan ROE masih belum mencapai standar industri. Demikian pula dengan rasio Cash Turnover, Credit Turnover dan Receivable Turnover yang belum mencapai standar industri. Kondisi ini menunjukkan bahwa LPD Desa Adat Penarukan perlu melalukan evaluasi dan meningkatkan efiensi serta efektivitas pengelolaan modal sendiri, aset serta piutang guna meningkatkan profitabilitas Lembaga Perkreditan Desa (LPD).
\end{abstract}

Kata kunci : Profitabilitas, Cash Turnover, Credit Turnover, dan Receivable Turnover

\begin{abstract}
Profitability Analysis of Village Credit Institutions Based on Cash Turnover, Credit Turnover, and Receivable Turnover. This study aims to determine the level of profitability of the Penarukan Traditional Village LPD using the ratio of Cash Turnover, Credit Turnover, and Receivable Turnover. The research method uses descriptive quantitative methods. Using LPD financial report data (secondary data) for 2018-2020. The results of the study found that the Net Profit Margin reached 26.8\%, it was appropriate. However, Gross Profit Margin, ROA and ROE still have not reached the industry standard. Likewise, the Cash Turnover, Credit Turnover and Receivable Turnover ratios have not yet reached industry standards. This condition indicates that the Penarukan Traditional Village Credit Institution needs to evaluate and improve the efficiency and effectiveness of managing its own capital, assets and receivables in order to increase the profitability of the Village Credit Institution (LPD).
\end{abstract}

Keywords: Profitabilitas, Cash Turnover, Credit Turnover, dan Receivable Turnover

\section{PENDAHULUAN}

Lembaga Perkreditan Desa (LPD) merupakan lembaga keuangan yang dimiliki oleh desa adat Di Bali yang melaksanakan operasionalnya dilingkungan desa adat. LPD adalah aset dan sumber pendapatan desa adat yang sangat penting bagi kemajuan perekonomian desa sehingga perlu dikelola dengan baik (Putra, 2013). LPD juga memiliki peranan yang sangat penting, yaitu meningkatkan taraf hidup warga desa sertamelestarikan keberadaan desa adat Di Bali. Menurut Peraturan Daerah Provinsi Bali No. 2 Tahun 1988 dan 
perbaharuannya yaitu Perda No. 8 Tahun 2002, LembagaPerkereditan Desa (LPD) memiliki peranan mendukung pembangunan ekonomi pedesaan melalui peningkatan minat menabung masyarakat pedesaan. Selain itu, LPD jugamenyediakan kredit usaha dengan skala kecil gunamenciptakan kesetaraan bagi pengusaha di pedesaan serta meningkatkan tingkat monetisasi di daerah pedesaan (Jayanti et al., 2020). PeraturanDaerah Provinsi Bali Nomor. 4 Tahun 2012, yang merupakan perubahan Peraturan Daerah Provinsi Bali Nomor 3 Tahun 2007 tentang Lembaga Perkreditan Desa (LPD), bahwa penting untuk melestarikan dan meningkatkan kemandirian kehidupan desa pekraman dengan segala aspeknya. Berdasarkan Peraturan Daerah Bali Nomor 4 tahun 2012, dicantumkan aktivitas operasional LPD diantaranya:menghimpun dana dari Krama Desa (masyarakat desa adat setempat) dalam bentuk tabungan dan deposito, memberikan pinjaman hanya kepada Krama Desa (masyarakat desa adat setempat). Modal LPD berasal dari swadaya masyarakat atau urunan krama desa dan bantuan pemerintah, serta hasil operasional atau keuntungan LPD itu sendiri.

Hasil keuntungan yang maksimal yang diperoleh oleh suatu LPD tentunya merupakan hasil pengelolaan manajemen keuangan yang mengelola aktiva dan utang dengan baik (Putra, 2013). Profitabilitas LPD akan digambarkan oleh pengelolaan manajemen aktiva dan utang secara finansial maupun nonfinansial. Guna memperoleh profitabilitas yang tinggi maka, LPD perlu memperhatikan pengelolaan aset secara sehat, pengelolaan fee base income yang kreatif, pengelolaan sumber dana yang efektif, serta pengelolaan pada biaya usaha yang efisien. Berdasarkan pemaparan tersebut memberikan penekanan bahwa, pengelolaan keuangan yang efektif dan efisien akan berdampak pada maksimalnya profitabilitas suatu LPD. Kondisi profitabilitas atau kemampuan penghasilan laba tentunya hampir dialami oleh semua LPD, termasuk LPD Desa Adat Penarukan. LPD Desa Adat Penarukan merupakan salah satu LPD Di Kabupaten Buleleng-Bali yang sejak 3 tahun terakhir yaitu sejak tahun 2018-2020 laba yang dihasilkan mengalami penurunan (Tabel 1).

Tabel 1

Laba LPD Desa Adat Penarukan Tahun 2018-2020

\begin{tabular}{llcc}
\hline Tahun & $\mathbf{2 0 1 8}$ & $\mathbf{2 0 1 9}$ & $\mathbf{2 0 2 0}$ \\
\hline Laba & Rp. 550.885.000 & Rp. 558.866.000 & Rp. 459.267.000 \\
\hline Sumber : Laporan & laba rugi LPD Desa Adat Penarukan Tahun 2018-2020)
\end{tabular}

Berdasarkan Tabel 1, selama 3 tahun terakhir LPD Desa Adat Penarukan mengalami penurunan keuntungan. Kondisi tersebut hendaknya segera ditindaklanjuti dengan melaksanakan pengkajian dan evaluasi terkait pengelolaan keuangan. Aktivitas perputaran kas, perputaran piutang, dan perputaran kredit pada LPD Desa adat Penarukan perlu dilakukan suatu pengkajian yang mampu memberikan informasi kondisi ketiga aspek keuangan tersebut.

Rasio perputaran kas (cash turnover) berkaitan dengan aliran perputaran kas pada suatu perusahaan termasuk LPD. Menurut (Firdaus, 2008), kas merupakan uang yang terdapat pada suatu perusahaan serta uang yang disimpan di bank yang bisa dipergunakan untuk membiayai aktivitas perusahaan. Apabila perusahaan maupun LPD mengalami kondisi perputaran kas yang kurang lancar maka aktivitas operasional LPD akan mengalami kendala. Kondisi tersebut tentunya berimplikasi terhadap tingkat profitabilitas atau kemampuan penghasilan laba LPD.

Rasio perputaran piutang (receivable turnover) merupakan rasio yang berkaitan tentang pengukuran lamanya waktu penagihan piutang selama satu periode atau jumlah 
perputaran dana piutang dalam satu periode (Kasmir, 2012). Merujuk pada pernyataan tersebut maka, semakin cepat proses perputaran piutang maka semakin baik kondisi keuangan perusahaan. Sebab, modal yang tertanam pada piutang tidak tertanam dalam jangka waktu lama. Atau dengan kata lain, proses penagihan piutang berjalan dengan baik. Terlebih LPD yang aktivitas utamanya menjalankan usaha simpan pinjam. Rasio perputaran kredit (credit turnover) berkaitan dengan volume kredit dan taksiran waktu pengumpulan utang dengan membagi total kredit dengan rata-rata kredit (Munawir, 2010). Saat menyalurkan kredit kepada nasabah perusahaan perlu mempertimbangkan modal kerja yang akan dialokasikan sebagai kredit yang akan disalurkan.

Rasio perputaran kas (cash trunover), rasio perputaran piutang (receivable turnover), dan rasio perputaran kredit (credit turnover) merupakan pengukuran yang penting dilakukan untuk mengetahui lebih detail profitabilitas LPD Desa Adat Penarukan. Pengkajian profitabilitas LPD Desa Adat Penarukan penting dilakukan sebab terjadinya penurunan laba sejak tahun 2018-2020. Diharapkan penelitian ini mampu memberikan informasi kondisi keuangan yang lebih jelas sehingga LPD Desa Adat Penarukan mampu mengambil keputusan selanjutnya. Berdasarkan fenomena tersebut, peneliti berpendirian untuk melakukan ini dengan judul " Analisis Profitabilitas Lembaga Perkreditan Desa Berdasarkan Cash Turnover, Credit Turnover dan Receivable Turnover”.

\section{KAJIAN LITERATUR}

Penelitian ini mengkaji tentang rasio perputaran kas (cash turnover), perputaran kredit (credit turnover) dan perputaran piutang (receiveble turnover) yang digunakan untuk menganalisa kondisi profitabilitas pada LPD Desa Adat Penarukan Di Kabupaten Buleleng. Adapun kajian literatur atau teori yang digunakan ialah :

\section{Profitabilitas Lembaga Perkreditan Desa (LPD)}

Profitabilitas merupakan indikator penting yang menggambarkan kinerja keuangan pada suatu perusahaan termasuk Lembaga Perkreditan Desa (LPD). Profitabilitas menggambarkan kemampuan perusahaan menghasilkan keuntungan atau laba dengan memanajemen sumber daya yang dimiliki misalnya seperti aktiva dan modal perusahaan (Sudana, 2011). Rasio ini sangat penting, sebab hasil akhir keuntungan yang diperoleh dari keputusan manajemen. Selain itu, pihak investor menggunakan tingkat kemampuan menghasilkan laba sebagai indikator utama dalam berinvestasi (Elisa, 2018). Menurut (Putra, 2013) terdapat beberapa faktor yang memperngaruhi profitabilitas pada suatu LPD diantaranya tingkat perputaran kas, tingkat perputaran piutang dan perputaran kredit dan jumlah nasabah kredit. Faktor-faktor tersebut menjadi faktor penting yang mempengaruhi profitabilitas LPD sebab ketiganya sangat berimplikasi dengan aktivitas utama LPD yaitu melayani pemberian kredit atau pinjaman kepada nasabah. Berikut empat analisis rasio yang digunakan untuk menilai tingkat profitabilitas, yaitu :

\section{Net Profit Margin (NPM)}

Net Profit Margin merupakan rasio yang digunakan untuk mengukur keuntungan perusahaan dengan membandingkan laba setelah pajak dengan volume penjualan. Net Profit Margin (NPM) menjadi sangat penting, melalui rasio ini pula terlihat ketepatan strategi dalam menentukan harga penjualan serta kemampuan mengendalikan beban usaha (Nengsih, 2020). Berikut persamaan Net Profit Margin (NPM) :

$$
\text { Net Profit Margin (NPM) }=\text { Laba Bersih Setelah Pajak }
$$

Penjualan

$$
x 100 \%
$$

\section{Gross Profit Margin (GPM)}

Gross Profit Margin (GPM) merupakan rasio yang digunakan untuk mengukur efisiensi produksi produk yang dijual. Pengukuran dilakukan dengan membandingkan 
laba kotor dengan penjualan.

3. Return On Assets (ROA)

Gross Profit Margin $(\mathrm{GPM})=$ Laba Kotor

Penjualan $\times 100 \%$

Return On Assets (ROA) menunjukkan perbandingan antara laba sebelum pajak dengan total aset. Rasio pengembalian aset ini digunakan untuk menilai profitabilitas atas total aset.

$$
\text { Return on Assets }(\mathrm{ROA})=\frac{\text { Laba Sebelum Pajak }}{\text { Total Aset }}
$$

4. Return On Equity (ROE)

Return On Equity (ROE) menunjukkan persentase laba bersih relatif dengan ekuitas pemegang saham. Melalui rasio ini akan terlihat tingkat pengembalian dana yang ditanamkan investor dalam perusahaan.

Return On Equity $(\mathrm{ROE})=$ Laba Setelah Pajak

Modal Sendiri

\section{Perputaran Kas (Cash Turnover)}

Kas merupakan sumber daya yang memiliki tingkat likuiditas paling tinggi. Kas atau uang tunai digunakan untuk memenuhi kebutuhan operasional sehari-hari perusahaan dan memenuhi kewajiban lancar perusahaan. Jumlah kas dalam suatu perusaan idealnya berjumlah 5\% hingga 10\% dari jumlah aktiva lancar (Guthman, 1953). Rasio perputaran kas (cash turnover) memperjelas apakah penggunaan kas sudah efisien atau tidak. Guna mengetahui kondisi tersebut maka, perlu dilakukan perbandingan antara jumlah pendapatan atau penjualan dengan rata-rata kas (Riyanto, 2011). Apabila tingkat perputaran kas tinggi, maka kas yang diinvestasikan pada aktiva semakin cepat. Tingkat perputaran kas yang tinggi juga menggambarkan tingkat penjualan yang tinggi (Nuriyani \& Zannati, 2017). Berikut rumus perputaran kas:

Perputaran kas $=$ Penjualan atau Pendapatan

Rata-Rata Kas

\section{Perputaran Piutang (Receivable Turnover)}

Perputaran piutang mencerminkan proses pemerimaan piutang atau proses penagihan piutang untuk dikembalikan kepada kas perusahaan pada periode tertentu (Putra, 2013). Selain itu, (Kasmir, 2012) juga menyatakan bahwa perputaran piutang menunjukkan lamanya waktu penagihan piutang selama satu periode. Tingkat perputaran piutang (receivable turnover) dapat diketahui dengan membandingkan tingkat credit sales selama periode tertentu dengan jumlah rata-rata piutang (average receivables) (Riyanto, 2011), sehingga dapat dirumuskan untuk menentukan perputaran piutang sebagai berikut :

Perputaran piutang $=$ Net Credit Sales

\section{Average Receivables}

\section{Perputaran Kredit (Credit Turnover)}

Jumlah nasbah yang dimiliki oleh suatu LPD berdampak terhadap keuntungan yang diperoleh LPD Hal ini disebabkan oleh sumber pendapatan utama LPD yang berasal dari bunga pemberian pinjaman kepada nasabah. Atau dengan kata lain, keuntungan LPD 
berasal dari bunga pinjaman yang dibebankan kepada nasabah. Jika proses penagihan kredit bermasalah, secara otomatis berdampak buruk pada keuntungan LPD (Susila, 2020). Melalui rasio perputaran kredit LPD dapat mengetahui jangka waktu perputaran kredit yang dapat ditagih. Jangka waktu pengembalian kredit sangat penting bagi LPD mengingat usaha utama LPD adalah memberikan pinjaman kredit kepada masyarakat desa atau nasabah. Waktu pengumpulan kredit diketahui dengan menghitung rata-rata kredit yang dikalikan dengan jumlah hari dalam setahun kemudian total kredit atau dengan membagi jumlah hari dalam setahun dengan tingkat perputaran kredit. Sedangkan rata-rata kredit dihitung dengan cara saldo awal tahun ditambah saldo akhir tahun di bagi dua (Munawir, 2010). Berikut rumus perhitungan RTO dan rata-rata kredit :

RTO $=\frac{\text { Kredit yang diberikan selama satu tahun }}{\text { Rata-rata kredit }}$

Rata-rata Kredit $=\quad$ Piutang awal tahun + Piutang akhir tahun

\section{METODE PENELITIAN}

Penelitian ini mengangkat permasalahan yang terjadi pada LPD Desa Adat Penarukan yang mengalami penurunan laba sejak tahun 2018-2020. Penurunan profitabilitas tersebut akan dianalisa menggunakan rasio perputaran kas (cash turnover), rasio perputaran piutang (receivable turnover), dan rasio perputaran kredit (credit turnover) yang sangat berpengaruh pada efektivitas menghasilkan laba. Penelitian ini menggunakan metode kuantitatif deskriptif. Jenis data yang digunakan ialah data sekunder berupa laporan keuangan LPD Desa Adat Penarukan sejak tahun 2018-2020. Teknik pengumpulan data yang ditempuh ialah dengan melaksanakan observasi dan dokumentasi.

\section{HASIL DAN PEMBAHASAN}

\section{Rasio Perputaran Kas (Cash Turnover) LPD Desa Adat Penarukan}

Adapun rumus yang digunakan untuk mengetahui rasio perputaran kas ialah :

Perputaran kas $=$ Penjualan atau Pendapatan

Rata-Rata Kas

Sehingga berdasarkan rumus tersebut ditemukan hasil :

$$
\text { Perputaran kas tahun } 2018=\frac{\text { Rp. } 550.885 .000}{\text { Rp. } 136.341 .000}
$$

$$
\text { Perputaran kas tahun } 2019=\frac{\text { Rp. } 588.866 .000}{\text { Rp.372.058.000 }}=1,58 \text { kali }
$$

Perputaran kas tahun $2020=$ Rp.459.267.000

Rp.187.268.000

Berdasarkan hasil perhitungan tersebut dapat diinterpretasikan bahwa pada tahun 2018 perputaran kas LPD Desa Adat Penarukan berjumlah 4 kali dalam satu periode. Sedangkan pada tahun 2019 mengalami penurunan yaitu berjumlah 1,58 kali. Kemudian pada tahun 
2020 perputaran kas LPD Desa Adat Penarukan mencapai 2,45 kali dalam satu periode. Hasil tersebut menjelaskan bahwa dalam satu periode pada tahun 2018-2020 tingkat perputaran kas paling tinggi ialah pada tahun 2018 yang berjumlah 4 kali.

Jika dalam satu periode berjumlah 360 hari maka lamanya dana tertanam selama 90 hari. Demikian pula pada tahun 2019 selama 228 hari dan pada tahun 2020 selama 147 hari. Kondisi tersebut mencerminkan kondisi perputaran kas LPD Desa Adat Penarukan yang masih perlu ditingkatkan. Sebab, menurut (Riyanto, 2011), semakin tinggi tingkat perputaran kas maka semakin efisien pengelolaan kas, jika perputaran kas masih rendah maka, tingkat efesiensi pengelolaan kas masih kurang kurang baik. Perputaran kas menunjukkan kecepatan perubahan kembali aset/aktiva lancar melalui penjualan. Sehingga dalam kurun waktu yang cepat pula kas dapat dimanfaatkan kembali untuk membiayai operasional sehingga kondisi keuangan perusahaan tidak mengalamikendala.

\section{Rasio Perputaran Piutang (Receivable Turnover) LPD Desa Adat Penarukan}

Guna mengetahui rasio perputaran piutang, digunakan rumus membandingkan tingkat credit sales selama periode tertentu dengan jumlah rata-rata piutang (average receivables), yaitu :

Perputaran piutang $=$ Net Credit Sales

Average Receivables

Berdasarkan rumus tersebut maka diketahui perputaran piutang pada LPD Desa Adat Penarukan sebagai berikut :

Perputaran piutang tahun $2018=$ Rp. $\quad 550.885 .000$

$$
\overline{1}=0,047 \mathrm{kali}
$$

Rp.11.626.396.000

$$
\text { Perputaran piutang tahun } 2019=\frac{\text { Rp. } \quad 588.866 .000}{\text { Rp.11.362.589.500 }}=0,052 \text { kali }
$$

$$
\text { Perputaran piutang tahun } 2020=\frac{\text { Rp. } \quad 459 \cdot 267 \cdot 000}{\text { Rp. } 11 \cdot 521 \cdot 011.000}=0,04 \text { kali }
$$

Sesuai dengan hasil perhitungan tersebut, maka dapat diinterpretasikan bahwa pada tahun 2018 perputaran piutang LPD Desa Adat Penarukan mencapai 0,047 kali dalam satu periode.Pada tahun 2019, perputaran piutang LPD Desa Adat Penarukan berjumlah 0,052 kali dalam satu periode. Sedangkan pada tahun 2020, perputaran piutang mencapai 0,04 kali. Menurut (Sutrisno, 2012), standar industri rasio perputaran piutang ialah 15 kali dalam satu periode. Namun, hasil perhitungan rasio perputaran piutang LPD Desa Adat Penarukan masih jauh dari standar industri. Sehingga, kondisi keuangan LPD Desa Adat Penarukan tentunya mengalami situasi yang kurang baik. Hasil tersebut menandakan bahwa, banyak piutang yang ditagih dalam kondisi tidak lancar.

Melalui rasio perputaran piutang ini akan diketahui berpa kali dana yang dialokasikan sebagai kredit yang dijual mengalami perputaran pada suatu waktu tertentu (Kasmir, 2012). Rendahnya perputaran piutang yang terjadi pada LPD Desa Adat Penarukan sangat perlu untuk ditingkatkan, mengingat sumber utama pendapatan LPD berasal dari keuntungan simpan pinjam atau kelancaran pembayaran kredit oleh nasabah. Pihak manajemen harus lebih memperhatikan kualitas seleksi pemberian kredit untuk meminimalisasi resiko piutang tak tertagih. 


\section{Rasio Perputaran Kredit (Credit Turnover) LPD Desa Adat Penarukan}

Rasio perputaran kredit dihitung dengan rumus berikut :

Rasio perputaran kredit $(\mathrm{RTO})=$ Kredit yang diberikan selama satu tahun

Rata-rata kredit

Sehingga dapat dihitung perputaran kredit pada LPD Desa Adat Penarukan sebagai berikut : Rasio perputaran kredit (RTO) tahun $2018=$ Rp. 7.986.574.000

Rp.11.626.396.000

Rasio perputaran kredit (RTO) tahun $2019=$

Rp. 7.895.567.500

Rp.11.362.589.500

Rasio perputaran kredit (RTO) tahun $2020=$ Rp. 7.719.818.000

$$
\frac{\text { Rp.11.521.011.000 }}{\text { Re }}=0,67 \text { kali }
$$

Berdasarkan hasil perhitungan tersebut, maka dapat diinterpretasikan bahwa kondisi rasio perputaran kredit LPD Desa Adat Penarukan masih sangat kecil dan rentang waktu yang lama. Pada tahun 2018 dengan tingkat perputaran berjumlah 0,69 kali maka dalam satu periode (360 hari) maka kredit tertanam selama 522 hari. Tahun 2019 selama 513 hari, demikian pula pada tahun 2020 selama 538 hari. Jika dibandingkan tentunya sudah melebihi waktu satu periode 360 hari.

Kondisi ini menunjukkan bahwa cukup banyak kredit macet yang terjadi di LPD Desa Adat Penarukan. Menurut (Munawir, 2010), semakin cepat perputaran kredit dalam satu periode maka semakin efisien alokasi piutang pada modal kerja. Namun yang terjadi pada LPD Desa Adat Penarukan ialah pengelolaan kredit atau piutang pada modal kerja masih sangat kurang efisien atau masih terjadi over investment pada piutang.

\section{Rasio Profitabilitas LPD Desa Adat Penarukan}

Rasio profitabilitas merupakan rasio yang menggambarkan kemampuan LPD menghasilkan laba atau keuntungan. Menurut (Sanjaya \& Rizky,2018) berdasarkan nilai rasio profitabilitas pihak manajemen perusahaan menentukan keputusan manajemen. Terdapat empat rasio yang digunakan untuk mengukur profitabilitas perusahaan, yaitu Net Profit Margin (NPM), Gross Profit Margin (GPM), Return On Assets (ROA), Return On Equity (ROE).

1. Net Profit Margin (NPM)

$$
\begin{gathered}
\text { Net Profit Margin (NPM) }=\frac{\text { Laba Bersih Setelah Pajak }}{\text { Penjualan }} \\
=\frac{\text { Rp. } 459.267 .000}{\text { Rp. } 1.714 .418 .000} \times 100 \% \\
=26,8 \%
\end{gathered}
$$

Menurut (Sutrisno, 2012), terkait standar industri rasio profitabilitas khususnya Net Profit Margin (NPM) ialah 20\%. Namun menurut (Gunawan, 2017), Net Profit Margin (NPM) tidak memiliki patokan ideal, pernyataan tersebut sesuai 
dengan yang disampaikan oleh (Harahap, 2010), yang menyatakan bahwa Net Profit Margin merupakan hasil pendapatan bersih yang diperoleh perusahaan dari hasil penjualan. Berdasarkan hasil perhitungan Net Profit Margin (NPM) pada LPD Desa Adat Penarukan mencapai 26,8\%. Semakin tinggi persentase Net Profit Margin (NPM) maka semakin baik kondisi keuangan LPD Desa Adat Penarukan.

2. Gross Profit Margin (GPM)

$$
\begin{aligned}
\text { Gross Profit Margin }(G P M)= & \frac{\text { Laba Kotor }}{\text { Penjualan }} \times 100 \% \\
= & \frac{\text { Rp. } \quad 513.520 .000}{\text { Rp. } 1.714 .418 .000} \times 100 \%
\end{aligned}
$$

$$
=29,9 \%
$$

Menurut (Kasmir, 2012), Gross Profit Margin (GPM) suatu perusahaan memiliki standar industri yaitu minimal 30\%. Berdasarkan hasil perhitungan, Gross Profit Margin (GPM) pada LPD Desa Adat Penarukan mencapai 29,9\%. Nilai rasio Gross Profit Margin (GPM) LPD Desa Adat Penarukan belum mencapai standar industri. Hal ini menunjukkan bahwa 29,9\% keuntungan LPD Desa Adat Penarukan digunakan sebagai dana untuk operasional pemberian kredit atau produksi produk oleh LPD. Hasil laba yang diperoleh LPD Desa Adat Penarukan digunakan untuk menutupi biaya operasional dan biaya tetap. Semakin tinggi rasio Gross Profit Margin (GPM) maka semakin baik tinggi kemampuan perusahaan dalam menghasilkan laba.

3. Return On Assets (ROA)

$$
\begin{aligned}
\text { Return on Assets }(\mathrm{ROA}) & =\frac{\text { Laba Sebelum Pajak }}{\text { Total Aset }} \times 100 \\
& =\frac{\text { Rp. } \quad 513.520 .000}{\text { Rp. } 14.441 .122 .000} \times 100 \% \\
& =3,56 \%
\end{aligned}
$$

Berdasarkan hasil perhitungan, Return On Assets (ROA) di LPD Desa Adat Penarukan mencapai 3,56\%. Menurut (Lukviarman, 2006), standar industri Return On Assets (ROA) ialah 5,98\%. Jika dibandingkan dengan standar industri, LPD Desa Adat Penarukan belum mencapai standar industri, sehingga perlu adanya peningkatan efiensi pengelolaan aset. Besaran nilai ROA pada LPD Desa Adat Penarukan menunjukkan bahwa pengelolaan aset yang masih kurang efisien. Sebab ROA mencerminkan nilai kemampuan LPD Desa Adat Penarukan menghasilkan laba berdasarkan dana yang tertanam pada aset yang dikelola. Hendaknya LPD Desa Adat Penarukan melakukan pengelolaan aset yang lebih efektif dan efesien.

4. Return On Equity (ROE)

$$
\begin{aligned}
\text { Return On Equity }(\mathrm{ROE}) & =\frac{\text { Laba Setelah Pajak }}{\text { Modal Sendiri }} \times 100 \% \\
& =\frac{\text { Rp. } \quad 459.267 .000}{\text { Rp. } 1.812 .700 .000} \times 100 \% \\
& =25,33 \%
\end{aligned}
$$


Hasil perhitungan menunjukkan bahwa nilai Return On Equity (ROE) pada LPD Desa Adat Penarukan mencapai 25,33\%. Standar industri Return On Equity (ROE) menurut (Kasmir, 2012), untuk Return On Equity (ROE) yang baik minimal 40\%. Namun LPD Desa Adat Penarukan hanya mencapai 25,33\%. Hal ini mengharuskan LPD Desa Adat Penarukan untuk melakukan evaluasi terhadap pengelolaan keuangan, terutama yang berkaitan dengan pengelolaan modal sendiri dalam menghasilkan laba. Berdasarkan hasil perhitungan dapat diinterpretasikan bahwa, setiap modal sendiri Rp. 100,00 yang tertanam dalam LPD Desa Adat Penarukan telah menghasilkan laba bersih sebesar Rp. 25,33. Semakin tinggi Rasio Return On Equity (ROE) maka perusahaan digambarkan menghasilkan laba yang lebih tinggi.

\section{SIMPULAN}

Berdasarkan hasil penelitian yang telah dilakukan, dapat disimpulkan bahwa, analisis profitabilitas menggunakan rasio perputaran kas (cash turnover), rasio perputaran kredit (credit turnover) dan rasio perputaran piutang (receivable turnover), ditemukan bahwa kondisi keuangan LPD Desa Adat Penarukan kurang baik. Sebab tingkat perputaran kas, perputaran piutang dan kredit masih tergolong rendah. Rendahnya rasio perputaran kas, perputaran piutang dan perputaran kredit berdampak pada kemampuan menghasilkan laba LPD Desa Adat Penarukan.

Analisis profitabilitas menggunakan rasio Net Profit Margin, Gross Profit Margin, Return On Assets, dan Return On Equity diperoleh hasil bahwa Net Profit Margin (NPM) pada LPD Desa Adat Penarukan 26,8\% sudah melebihi standar industri 20\%. Namun masih perlu ditingkatkan karena Gross Profit Margin, Return On Assets, dan Return On Equity belum mampu mencapai kriteria standar industri. Hal ini mengindikasikan bahwa, laba yang dihasilkan oleh LPD Desa Adat Penarukan belum maksimal. Pengelolaan modal sendiri dan aset masih perlu dievaluasi dan lebih ditingkatkan guna memaksimalkan penghasilan laba.

\section{REFERENSI}

Elisa. (2018). Analisa Rasio Laporan Keuangan Pada Pt. Jasa Sarana Citra Bestari Cabang Bengkalis Menurut Perspektif Islam. Jurnal Akuntansi Syariah, 2 No 1.

Firdaus, D. (2008). Pengantar Akuntansi (Ketiga). F.E Universitas Indonesia.

Gunawan, L. (2017). Pengaruh Net Profit Margin Dan Total Asset Turnover Terhadap Nilai Perusahaan Pada Sektor Industri Barang Konsumsi Yang Terdaftar Di Bursa Efek Indonesia. Jurnal Mabis Stie Widya Dharma Pontianak, 1, 105-112.

Guthman, H. . (1953). Analysis of Financial Statements.

Harahap, S. S. (2010). Analisa Kritis atas Laporan Keuangan. PT RajaGrafindo Persada.

Jayanti, I., Noor, M., \& Anggraeiny, R. (2020). Kualitas Pelayanan Lembaga Perkreditan Desa ( Lpd ) Di Desa Argo Mulyo Kecamatan Sepaku Kabupaten Penajam Paser Utara. EJournal IImu Administrasi Negara, 8(3), 9344-9356.

Kasmir. (2012). Analisis Laporan Keuangan (Kelima). PT. Raja Grafindo Persada.

Lukviarman, N. (2006). Dasar Dasar Manajemen Keuangan. Andalas University Press.

Munawir. (2010). Analisis Laporan Keuangan (Keempat). Liberty.

Nengsih, R. (2020). Pengaruh Current Ratio, Net Profit Margin dan Modal Terhadap Nilai Perusahaan Jurnal

Humaniora, $4(1)$, $120-129$. 
http://jurnal.abulyatama.ac.id/humaniora

Nuriyani \& Zannati. (2017). Pengaruh Perputaran Kas Dan Perputaran Piutang Terhadap Profitabilitas Perusahaan Sub-Sektor Food And Beverages Tahun 2012-2016. Jurnal Riset Manajemen Dan Bisnis (JRMB) Fakultas Ekonomi UNIAT.

Putra, S. I. W. (2013). E-Jurnal Akuntansi Universitas Udayana. Pengaruh Tingkat Perputaran Kas, Piutang Dan Jumlah Nasabah Kredit Pada Profitabilitas Lpd Di Kecamatan Ubud.

Riyanto, B. (2011). Dasar-Dasar Pembelanjaan Perusahaan (Keempat). BPFE.

Sanjaya, Surya \& Rizky, M. . (2018). Analisis Profitabilitas Dalam Menilai Kinerja Keuangan Pada PT. Taspen (Persero) Medan.

Sudana, M. (2011). Manajemen Keuangan Perusahaan Teori dan Praktek. Erlangga.

Susila, G. (2020). Dampak Tingkat Perputaran Kas, Perputaran Piutang dan Jumlah Nasabah Kredit terhadap Profitabilitas. JIA (Jurnal Ilmiah Akuntansi), 5(2), 308-324.

Sutrisno. (2012). Manajemen Keuangan Teori, Konsep dan Aplikasi. EKONOSIA. 